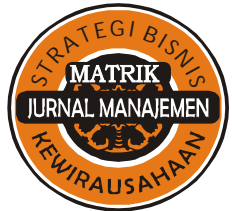

P-ISSN : 1978-2853 E-ISSN : 2302-8890

\section{MATRIK: JURNAL MANAJEMEN, STRATEGI BISNIS DAN KEWIRAUSAHAAN}

Homepage: https://ojs.unud.ac.id/index.php/jmbk/index

Vol. 14 No. 1, Februari 2020, 82-93

\title{
Pengaruh Dana Pihak Ketiga dan Kinerja Perbankan Nasional terhadap Penerbitan Indonesia Government Securities
}

\author{
Batara Maju Simatupang \\ Magister Manajemen STIE Indonesia Banking School, Jakarta \\ email : batara.ms@ibs.ac.id
}

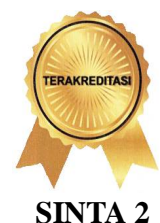

DOI : https://doi.org/10.24843/MATRIK:JMBK.2020.v14.i01.p09

\begin{abstract}
ABSTRAK
Tujuan studi secara kuantitatif ini untuk mengetahui pengaruh dana pihak ketiga (TPF) dan kinerja perbankan nasional terhadap penerbitan Indonesia Government Securities (IGS). Teknik analisis data yang digunakan adalah regressi berganda dengan variabel tergantung jumlah outstanding IGS (OSIGS) dan kinerja perbankan nasional. Variabel bebas dari kinerja perbankan nasional terdiri rasio kecukupan modal (CAR), rasio imbal-balik aset (ROA), biaya operasional terhadap pendapatan operasional (OEOI/BOPO), rasio bagian pendapatan bersih (NIM), dan rasio pinjaman terhadap dana (LDR). Periode data penelitian dimulai dari tahun 2007S1-2016S1 dengan data konsolidasi kinerja perbankan nasional dari seluruh jumlah bank umum (commercial bank) sebanyak 118 bank. Hasil penelitian ini mendapatkan bahwa: (1) TFP dan CAR berpengaruh negatif terhadap kenaikan outstanding IGS; (2) LDR tetap bertumbuh kendati kenaikan outstanding IGS meningkat; dan (3) ROA, OEOI dan NIM tidak mempengaruhi pertumbuhan oustanding IGS. Implikasinya terhadap dana pihak ketiga secara langsung berhadapan dengan pemerintah dalam penghimpunan dana melalui penerbitan IGS.
\end{abstract}

Kata kunci: Obligasi, dana pihak ketiga, kinerja perbankan.

The Effect of Third Party Funds and National Banking Performance on The Issuance of Indonesia Government Securities

\section{ABSTRACT}

The objective of this quantitative study is to determine the effect of third-party funds (TPF) and the performance of national banks on the issuance of Indonesia Government Securities (IGS). The data analysis approach used is multiple regression with dependent variables of the outstanding IGS (OSIGS) and national banking performance. The independent variables of national banking performance consist of capital adequacy ratio (CAR), asset return ratio (ROA), operating costs against operating income (OEOI/ BOPO), net income share ratio (NIM), and the ratio of loans to funds (LDR). The data period of the study began from 2007S1-2016S1 with consolidated data on the performance of national banks from all the commercial banks as many as 118 banks. The results of this study find that: (1) TFP and CAR harm the increase in outstanding IGS; (2) LDR continues to grow despite an increase in outstanding IGS increases; and (3) ROA, OEOI and NIM do not affect IGS comparative growth. The implication for third-party funds is directly dealing with the government in raising funds through the issuance of IGS.

Keywords: Securities, third party fund, and banking performance.

\section{PENDAHULUAN}

Direktorat Jenderal Pengelolaan Pembiayaan dan Risiko (DJPPR) Kemenkeu RI edisi April 2016, menyatakan bahwa Utang merupakan bagian dari kebijakan fiskal (APBN: Anggaran Pendapatan dan Belanja Negara) yang menjadi bagian dari kebijakan pengelolaan ekonomi secara keseluruhan. Lebih lanjut disampaikan bahwa pembiayaan APBN melalui utang merupakan bagian dari pengelolaan keuangan negara yang lazim dilakukan oleh suatu negara.
Pada prakteknya, utang akan mencuat bilamana Pemerintah mengalami defisit anggaran. Umumnya anggaran aktual dipisahkan ke dalam komponen struktural dan komponen siklikal (Samuelson \& Nordhaus, 2010). Anggaran struktural menghitung, seberapa banyak pemerintah menerima dan membelanjakannya, bilamana perekonomian bekerja pada tingkat output potensial. Sedangkan anggaran siklikal menghitung dampak turun naiknya usaha terhadap pendapatan pajak, pengeluaran dan defisit. 
Samuelson mengingatkan bahwa untuk mengukur dampak kebijakan fiskal terhadap perekonomian, harus memperhatikan defisit struktural, dimana perubahan dalam perekonomian, harus memperhatikan defisit struktural, dimana perubahan dalam perekonomian, akan mengakibatkan terjadinya defisit siklikal.

Tabel 1. Komposisi Pinjaman dan Surat Utang Negara

\begin{tabular}{|c|c|c|c|c|c|c|c|c|c|}
\hline \multirow[t]{2}{*}{ NEGARA } & \multirow[t]{2}{*}{2011} & \multirow[t]{2}{*}{2012} & \multirow[t]{2}{*}{2013} & \multirow[t]{2}{*}{2014} & \multirow[t]{2}{*}{2015} & \multicolumn{2}{|c|}{ Per Juni 2016} & & \\
\hline & & & & & & Nominal & $\%$ Total & & \\
\hline A. PINJAMAN & 621,29 & 616,61 & 714,44 & 677,56 & 755,12 & 739,99 & $22,0 \%$ & & \\
\hline $\begin{array}{ll}\text { - } & \text { Pinjaman } \\
& \text { Luar Negeri }\end{array}$ & & & & & 751,04 & 735,43 & $21,9 \%$ & & \\
\hline 1. Bilateral & & & & & 340,63 & 340,63 & $10,1 \%$ & & \\
\hline 2. Multilateral & & & & & 360,04 & 347,06 & $10,3 \%$ & & \\
\hline $\begin{array}{l}\text { 3. Komersial } \\
\text { Bank }\end{array}$ & 25,15 & 24,37 & 40,00 & 47,15 & 50,20 & 47,58 & $1,4 \%$ & & \\
\hline 4. Suppliers & 0,50 & 0,41 & 0,35 & 0,24 & 0,17 & 620,28 & 614,81 & 712,17 & 674,33 \\
\hline $\begin{array}{l}\text { - Pinjaman } \\
\text { Dalam } \\
\text { Negeri }\end{array}$ & 1,01 & 1,80 & 2,27 & 3,22 & 4,08 & 381,66 & 359,80 & 383,53 & 334,62 \\
\hline $\begin{array}{ll}\text { B. } & \text { SURAT } \\
\text { UTANG } \\
\text { NEGARA }\end{array}$ & $1.187,66$ & $1.361,10$ & $1.661,05$ & $1.931,22$ & 2410,01 & 212,96 & 230,23 & 288,29 & 292,33 \\
\hline $\begin{array}{l}\text { Denominasi } \\
\text { Valas }\end{array}$ & 195,63 & 264,91 & 399,40 & 456,62 & 658,92 & 715,44 & $21,3 \%$ & & \\
\hline $\begin{array}{l}\text { Denominasi } \\
\text { Rupiah }\end{array}$ & 992,03 & $1.096,19$ & $1.261,65$ & $1.474,60$ & $1.751,09$ & $1.907,31$ & $56,7 \%$ & & \\
\hline $\begin{array}{l}\text { TOTAL } \\
\text { UTANG }\end{array}$ & $1.808,95$ & $1.977,71$ & $2.375,50$ & $2.608,78$ & $3.165,13$ & $3.362,74$ & $100,0 \%$ & & \\
\hline
\end{tabular}

Sumber: DJPPR Kemenkeu RI, 2016

Defisit siklikal secara implisit mengeksplor kebijakan Pemerintah bahwa defisit anggaran Pemerintah akan mendesak investasi (crowding out), bukannya merangsang investasi. Solusi dalam mengatasi defisit, sesuai dengan kebijakan pengelolaan ekonomi yang dianut, Pemerintah dapat menciptakan utang. Penciptaan utang dapat diperoleh dari pinjaman komersil dari bank, baik dari dalam maupun luar negeri, dan atau menerbitkan Indonesia Government Securities (IGS) secara paralel.

Pada Tabel 1 yang disajikan di atas, komposisi pinjaman dan surat utang negara, dimana posisi IGS dari tahun ketahun meningkat dan posisi per Juni 2016 sudah mencapai IDR2.622,75 triliun (78.0\% dari total utang IDR3.362,74 triliun). Kebijakan Pemerintah yang secara periodik menurunkan jumlah utang lewat pinjaman dan meningkatkan utang lewat penerbitan obligasi, hal ini sejalan dengan hasil riset yang dikemukakan oleh Islam (2014) bahwa komponen utang dalam bentuk surat berharga negara (SBN) lebih efektif dibandingkan dengan pinjaman Pemerintah dalam mendorong pertumbuhan ekonomi.

Kenaikan jumlah nominal utang Pemerintah berasal dari akumulasi utang dimasa lalu (legacy debts) yang memerlukan pembiayaan yang cukup besar, termasuk obligasi rekapitalisasi perbankan yang diterbitkan oleh Pemerintah sebesar IDR430.4 triliun atau $67 \%$ dari total biaya restrukturisasi perbankan nasional pada tahun 2000, yaitu sebesar IDR658.72 triliun (Simatupang, 2007; Simatupang, 2012).

DJPPR Kemenkeu RI (2016) menegaskan bahwa sejak tahun 2005, IGS menjadi instrumen utama pembiayaan APBN, dimana kenaikan IGS periode 2011-2016, antara lain untuk pembiayaan utang lama yang jatuh tempo, dan pembiayaan dilakukan dengan utang baru yang mempunyai ketentuan dan kondisi yang lebih baik, disajikan pada Gambar 1.

Berdasarkan gambar 1 dapat dilihat bahwa persentase defisit anggaran terhadap PDB (produk domestik bruto) masih di bawah 3\%, belum melewati ambang batas dan pilihan penciptaan utang dalam komponen GS ternyata juga untuk memelihara likuiditas, ini sejalan dengan hasil penelitian oleh Kempf \& Uhrig-Homburg (2000), yang menyatakan bahwa GS (government securities) yang diterbitkan oleh pemerintah German pada periode 1992-1994 ternyata dapat memelihara likuiditas mereka. Hal ini sesuai dengan amanat UU No17/2003 ttg Keuangan Negara, besar defisit nasional yang diperkenankan adalah sebesar 3\% dari PDB yang bertujuan untuk memelihara likuiditas. Kendati rasio defisit terpelihara di bawah 3\%, namun akumulasi utang secara nominal terus membengkak dari periode 2011-2016 dengan CAGR (Compound Annual Growth Rate) sebesar 39,01\%. Bahkan, 


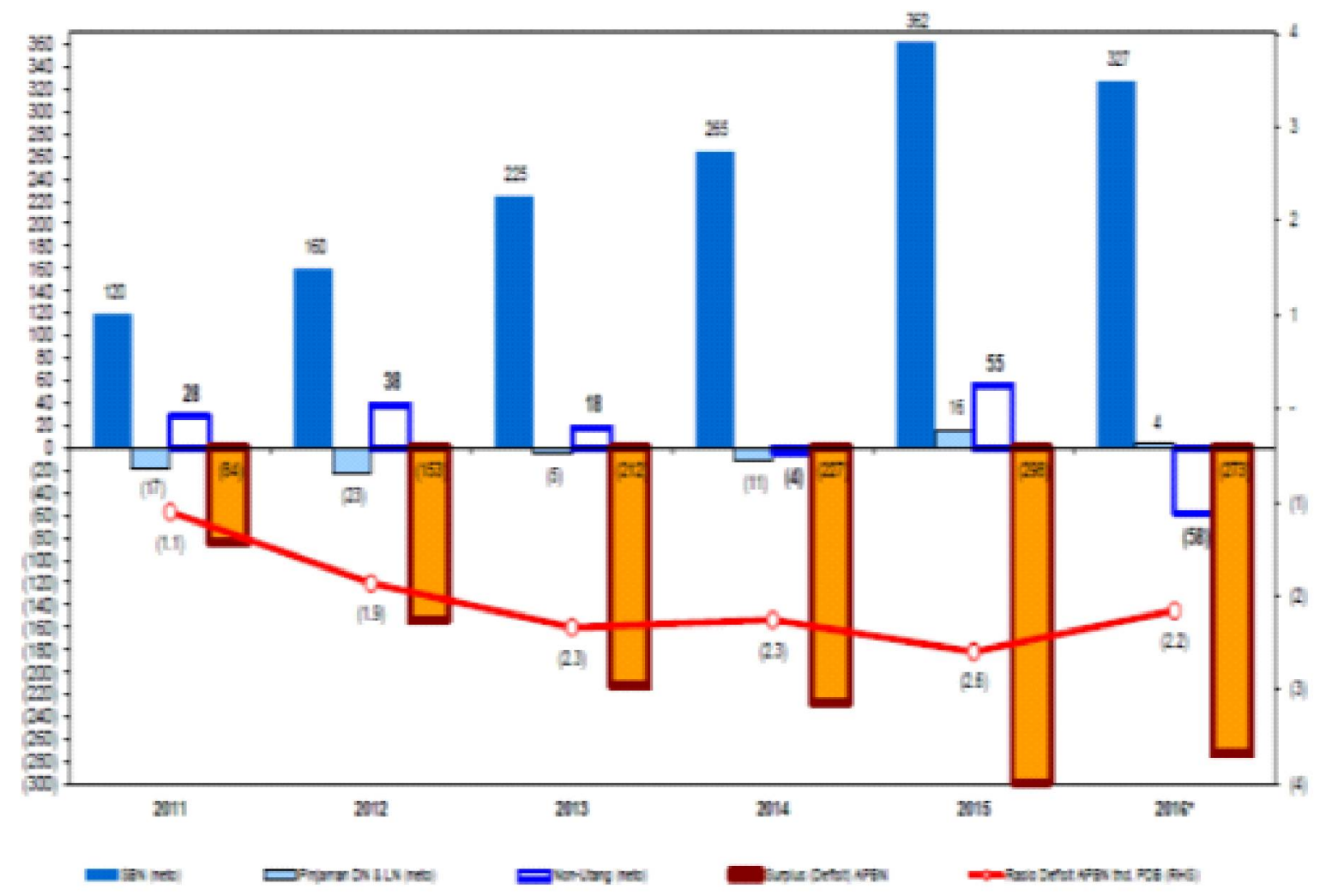

Gambar 1. Grafik Defisit dan Pembiayaan APBN 2011-2016

Sumber: DJPPR Kemenkeu 2016,9

dalam Laporan Keuangan Pemerintah Pusat (LKPP) oleh DJPBII-Kemenkeu (2016), dikemukakan bahwa dominansi alokasi pembiayaan defisit pada tahun 2015 berasal dari pembayaran utang yang mencapai IDR228,495 triliun atau 76,66\% dari defisit sebesar IDR298,495 triliun, dan untuk perkiraan di tahun 2016 pembayaran utang mencapai IDR303,641 triliun atau $111,15 \%$ dari defisit sebesar IDR273,179 triliun.

Berdasarkan penjelasan di atas, bila merujuk pada ketentuan penciptaan utang oleh Pemerintah dalam menambal defisit APBN, yaitu melalui mekanisme penerbitan IGS dan pinjaman dari pihak ketiga maksimum 3\% dari PDB, maka pembatasan ini sebagai barometer bagi Pemerintah untuk tidak membanjiri IGS dan pinjaman dalam berebut DPK (dana pihak ketiga) dengan perbankan nasional dan dana yang berpotensi masuk kepada IKNB (Institusi Keuangan Non Bank), ini sejalan dengan apa yang dikemukakan oleh Mishkin (2016) bahwa opsi dalam sumber anggaran pembangunan adalah melalui pajak dan utang atau penerbitan obligasi.

Terkait dengan penciptaan utang melalui obligasi, dari hasil analisis yang dilakukan Min (1998) pada yield spreads obligasi dari sebelas negara berkembang pada periode 1991-1995 menyatakan bahwa kemampuan mengakses pasar luar negeri sangat ditentukan faktor fundamental dalam negeri dan faktor eksternal masing-masing negara, sehingga untuk meningkatkan akses pasar obligasi internasional, Pemerintah harus meningkatkan fundamental ekonominya.

Terkait dengan fundamental ekonomi, Gibson et al. (2011) menyatakan bahwa faktor likuiditas atau aliran modal berkaitan dengan kemampuan suatu negara untuk mengakses mata uang asing yang dibutuhkan untuk menjual obligasi, seperti pertumbuhan ekspor, rasio cadangan devisa terhadap PDB berpengaruh negatif terhadap yield spread, sedangkan debt service ratio berpengaruh positif terhadap yield spread obligasi. Dari penjelasan ini, dapat dikatakan bahwa peningkatan fundamental ekonomi bukan saja memperkuat perekonomian domestik, namun juga dapat merangsang pertumbuhan. Pertumbuhan ini sangat terkait dengan investasi yang dicerminkan oleh permintaan dan penawaran dana.

Penelitian yang dilakukan oleh Sihombing et al. (2013) menemukan bahwa pengembangan kurva hasil pada Obligasi Pemerintah Indonesia mengalami 
sebuah pergerakan yang fluktuatif, dipengaruhi oleh faktor likuiditas, fundamental makro ekonomi, faktor eksternal, dan faktor risiko pasar.

Hubbard (2001) menyatakan bahwa variabel yang dapat menggeser kurva permintaan dana dan menyebabkan suku bunga (yield) naik adalah naiknya ekspektasi keuntungan dari investasi, kenaikan subsidi pajak bagi investasi, kenaikan ekspektasi inflasi, dan kenaikan defisit anggaran Pemerintah. Sebaliknya, variabel yang dapat menggeser kurva pemintaan ke kiri sehingga suku bunga (yield) turun adalah adanya kenaikan pajak yang berdampak pada pengurangan keinginan berinvestasi. Terkait dengan yield spread, Chee \& Fah (2013) melakukan riset "Macro Economic Determinants of UK Treasury Bonds Spread" dan menyakan bahwa suku bunga jangka pendek berpengaruh negatif terhadap yield obligasi Pemerintah Inggris, sedangkan nilai tukar mempunyai hubungan signifikan dan berpengaruh positif terhadap yield obligasi. Sementara itu, untuk faktor makro ekonomi, seperti deflator PDB, PDB rill, international reserve, uang beredar riil, net trading, dan indeks saham tidak berpengaruh pada yield obligasi Pemerintah Inggris.

Berdasarkan paparan di atas, lebih spesifik, tulisan ini bertujuan untuk mengetahui pengaruh dana pihak ketiga (DPK) dan kinerja perbankan nasional terhadap penerbitan Surat Utang Pemerintah Indonesia (IGS) dalam hal ini outstanding IGS (OSIGS) yang tradable dan implikasinya bagi DPK perbankan nasional.

\section{METODE PENELITIAN}

Data yang digunakan adalah data runtun waktu, bulanan, mulai dari tahun 2007-2016S1. Data penerbitan IGS dan outstanding IGS tradable diperoleh dan diolah dari DJPPR Kemenkeu RI.Sayangnya, data yang tersedia adalah data outstanding IGS IDR saja, sedangkan data oustanding IDR dalam valuta asing belum dimasukkan dalam proses kajian. Pemilihan terhadap jumlah outstanding IGS yang dapat diperdagangkan, adalah untuk memastikan bahwa jumlah outstanding IGS yang dapat diperdagangkan (tradable) secara langsung dapat dipengaruhi oleh DPK perbankan nasional dan DPK pada IKNB. Sedangkan untuk dana pihak ketiga dan kinerja perbankan nasional diperoleh dari hasil konsolidasian yang dilakukan oleh Bank Indonesia (BI) dan OJK (Otoritas Jasa Keuangan) dalam bentuk Statistik Perbankan Indonesia (SPI).

Khusus untuk kinerja perbankan, variabel bebas yang digunakan adalah adobsi dari SPI terbaru dari $\mathrm{BI} / \mathrm{OJK}$, antara lain CAR (capital adequacy ratio), ROA (return on assets), OE/OI (operating expenses/ operating income atau BOPO (biaya operasional/pendapatan operasional), NIM (net interest income), dan LDR (loan to deposits ratio). Sedangkan LAR (liquid assets ratio) tidak digunakan, karena data mentah yang tersedia hanya dari tahun 2012 sampai dengan Juni 2016. Secara rinci sumber data yang digunakan dalam penelitian ini disajikan pada Tabel 2.

Tabel 2. Variabel dan Sumbery

\begin{tabular}{|c|c|c|c|}
\hline Variabel & Deskripsi & Tipe Data & Sumber Data \\
\hline OSIGS & Outstanding Amount of IGS (tradable) & Bulanan & $\begin{array}{c}\text { DJPPR } \\
\text { Kemenkeu }\end{array}$ \\
\hline TPF & Dana Pihak Ketiga (DPK) & Bulanan & SPI BI/OJK \\
\hline CAR & $\begin{array}{l}\text { Capital Adequacy Ratio / Rasio } \\
\text { Kecukupan Modal }\end{array}$ & Bulanan & SPI BI/OJK \\
\hline ROA & Return on Assets / Imbal Balik Aset & Bulanan & SPI BI/OJK \\
\hline OEOI & $\begin{array}{l}\text { Biaya Operasional terhadap Pendapatan } \\
\text { Operasional }\end{array}$ & Bulanan & SPI BI/OJK \\
\hline NIM & $\begin{array}{l}\text { Net Interest Margin / Pendapatan Bunga } \\
\text { Bersih }\end{array}$ & Bulanan & SPI BI/OJK \\
\hline LDR & $\begin{array}{l}\text { Loan To Deposits Ratio / Rasio } \\
\text { Pinjaman terhadap DPK }\end{array}$ & Bulanan & SPI BI/OJK \\
\hline \multicolumn{4}{|c|}{ Catatan: Penetapan variabel dependen dan independen } \\
\hline
\end{tabular}


Data-data variabel pada Tabel 2 di atas, khususnya untuk nilai nominal (OSIGS dan TPF) diubah terlebih dahulu dalam bentuk logaritma $(\log )$, sedangkan yang satuan unitnya dalam prosentase langsung dapat digunakan (CAR, ROA, OEOI, NIM, dan LDR).

$$
\begin{array}{rr}
\log (\text { OSIGS })_{t}= & \beta_{t}+\beta_{1} \log (T P F)_{t}+\beta_{2}(C A R)_{t}+\beta_{3}(R O A)_{t}+\beta_{4}(O E O I)_{t} \\
& +\quad \beta_{5}(N I M)_{t}+\beta_{6}(L D R)_{t}+\varepsilon_{t} \ldots \ldots \ldots \ldots \ldots \ldots \ldots \ldots \ldots \ldots \ldots \ldots \ldots \ldots
\end{array}
$$

Pada dasarnya persamaan empiris di atas dapat digunakan secara langsung, namun dikarenakan sifat data yang runtut waktu pada umumnya ada terjadi

$$
\begin{aligned}
D \log (\text { OSIGS })_{t} & =\beta_{t}+\beta_{1} D \log (T P F)_{t}+\beta_{2} D(C A R)_{t}+\beta_{3} D(R O A)_{t}+\beta_{4} D(O E O I)_{t} \\
& +\beta_{5} D(N I M)_{t}+\beta_{6} D(L D R)_{t}+\varepsilon_{t}
\end{aligned}
$$

Keterangan:

$\begin{array}{ll}\text { OSIGS } & : \text { OutstandingIGS tradable (IDR } \\ & \text { Triliun, dalam bentuk logaritma) } \\ \text { TPF } & : \begin{array}{l}\text { Third Party Fund (IDR Triliun, dalam } \\ \text { bentuk logaritma) }\end{array} \\ \text { CAR } & : \text { Capital Adequacy Ratio (persentase) } \\ \text { ROA } & : \text { Return on Assets (persentase) } \\ \text { OEOI } & : \text { Operating Expense/ Operating } \\ & \text { Income (persentase) } \\ \text { NIM } & : \text { Net Interest Margin (persentase) } \\ \text { LDR } & : \text { Loan to Deposits Ratio (persentase) } \\ & : \text { Residual }\end{array}$

Ada persamaan model empiris di atas (2), maka akan dilakukan pemeriksaan adanya stasioneritas dengan metode uji akar unit (unit root test) dengan menggunakan Augmented Dickey-Fuller Test Equation. Apabila data didapati sudah stasioner, maka akan dilakukan estimasi parameter dengan menggunakan ordinary least square (OLS) melalui pengujian asumsi klasik dalam OLS. Selanjutnya, untuk memastikan tidak ada pelanggaran terhadap asumsi multikolonieritas, auotokorelasi dan juga heteroskedastisitas maka secara berturut-turut dilakukan uji multikoloniariti, uji durbin watson (DW) untuk residual dan white heteroskedasticity test.

\section{HASIL DAN PEMBAHASAN}

Selama periode penelitian 2007S1-2016S1, IGS yang diterbitkan oleh Pemerintah secara alami akan membawa konsekuensi kepada kemampuan perbankan dalam menghimpun DPK. Dalam riset yang dilakukan oleh Islam (2014) dengan metode estimasi VECM (vector error correction model) didapati bahwa secara umum utang pemerintah berpengaruh positif dan signifikan terhadap pertumbuhan PDB dengan koefisian 0,582, artinya bilamana terjadi kenaikan utang pemerintah sebesar satu persen, maka akan mendorong pertumbuhan sebesar $0,582 \%$. Juga disimpulkan, bahwa komponen utang dalam bentuk pinjaman memiliki pengaruh negatif terhadap pertumbuhan dengan elastisitas $-0,273$, namun sebaliknya, komponen utang dalam bentuk IGS memiliki pengaruh positif dan signifikan dalam mendorong pertumbuhan. Implikasi dari penelitian ini adalah membawa dampak positif kepada sistem pembayaran dan pengelola DPK, yaitu industri perbankan dan IKNB.

Riset yang dilakukan Septiana (2010) menyatakan bahwa penerbitan obligasi subornisasi akan menaikkan kinerja bank, khususnya akan meningkatkan CAR perbankan. Demikian juga penelitian yang dilakukan oleh Sapulete \& Manurung (2014) terhadap penerbitan obligasi subordinasi yang dijadikan komponen modal berpengaruh secara signifikan terhadap ROA dan NPL, namun hanya NPL yang signifikan mempengaruhi NIM, hal ini juga sejalan dengan penelitian Ariyanto, (2011).

Hendar (2012) mengatakan bahwa sejak 2005, pemerintah telah mengubah sumber defisit pembiayaan dari utang luar negeri ke dalam negeri melalui penerbitan surat berharga Pemerintah. Sementara itu, ekses likuiditas global telah mendorong investor asing untuk mencari hasil yang lebih tinggi. Dengan fundamental yang kuat dan hasil yang menarik, Indonesia telah menjadi penerima aliran modal besar-besaran, yang sebagian besar 
telah diinvestasikan kedalam saham dan obligasi Pemerintah.

Mehrotra et al. (2012) mendapati bahwa pasar obligasi Pemerintah domestik di EME (Emerging Market Economy) telah berkembang dengan kedalaman pasar yang meningkat, jatuh tempo telah diperpanjang dan basis investor umumnya melebar, meskipun tingkat kemajuan bervariasi di berbagai negara dan masih ada beberapa kekurangan. Ekspansi pasar IGS di Indonesia juga mengalami volatilitas yang berasal dari pasar, termasuk adanya kepemilikan asing pada obligasi Pemerintah.

Kecenderungan pertumbuhan outstanding IGS (OSIGS) yang lebih tinggi dibandingkan dengan pertumbuhan outstanding TFP adalah sebagai indikasi bahwa pertumbuhan TFP dipengaruhi oleh meningkatnya uang giral, sedangkan pertumbuhan oustanding IGS dibatasi oleh besarnya defisit APBN yang menimbulkan utang yang berkesinambungan.

Berdasarkan output statistik deskriptif pada Tabel 3 berikut ini, dapat dideskripsikan bahwa outstanding IGS memiliki rata rata (mean) IDR 824.32 triliun dengan nilai maksimum oustanding sebesar IDR 1.646,85 triliun yang terdapat diakhir periode 2016S1 dengan standar deviasi sebesar 334.09 yang digunakan untuk mengartikulasikan besarnya volatilitas dari outstanding IGS.

Tabel 3. Output Statistik Deskriptif

\begin{tabular}{lccccccc}
\hline & OSIGS & TFP & CAR & ROA & OEOI & NIM & LDR \\
\hline Mean & 824.3257 & 2659.252 & 19.03916 & 2.802762 & 83.61220 & 4.060844 & 79.5939 \\
Median & 707.9925 & 2482.861 & 18.57000 & 2.905000 & 83.66500 & 4.799384 & 78.01001 \\
Maximum & 1646.846 & 4397.620 & 23.02000 & 3.700000 & 118.2400 & 6.060000 & 92.11001 \\
Minimum & 423.3906 & 1279.566 & 16.44000 & 2.270000 & 73.74000 & 0.463290 & 60.55001 \\
Std. Dev. & 334.0984 & 982.8845 & 1.777187 & 0.297206 & 6.680056 & 1.617274 & 8.57884 \\
Skewness & 0.857670 & 0.273800 & 0.428299 & -0.123858 & 1.398248 & -0.896258 & $-0.31586 !$ \\
Kurtosis & 2.590437 & 1.714867 & 1.971829 & 2.894858 & 8.509223 & 2.448920 & 2.13857 \\
\hline Jarque-Bera & 14.77314 & 9.269306 & 8.506765 & 0.343986 & 181.3167 & 16.70482 & 5.42042 \\
Probability & 0.000620 & 0.009709 & 0.014216 & 0.841985 & 0.000000 & 0.000236 & 0.06652 ' \\
\hline Sum & 93973.13 & 303154.7 & 2170.464 & 319.5148 & 9531.791 & 462.9362 & $9073.70 !$ \\
Sum Sq. Dev. & 12613255 & $1.09 \mathrm{E}+08$ & 356.8984 & 9.981455 & 5042.416 & 295.5600 & 8316.41 \\
\hline Observations & 114 & 114 & 114 & 114 & 114 & 114 & 114 \\
\hline
\end{tabular}

Sumber: Diolah menggunakan EViews Versi 9.

Untuk TFP (DPK) rata-rata sebesar IDR2.659,25 triliun, maksimum TFP sebesar IDR4.397,62 triliun dengan standar deviasi 982.88. Untuk kinerja perbankan rata-rata sebesar CAR $19,03 \%$, ROA $2,80 \%$, OEOI $83,61 \%$, NIM 4,06\%, dan LDR 79,59\%. Untuk standar deviasi kinerja perbankan secara berturut-turut dari yang terbesar adalah LDR 8,57, OEOI 6,68, CAR 1,77, NIM 1,61, dan ROA 0,29.

Untuk mengetahui normalitas data, maka dapat dilihat dari angka uji Jarque-Bera. Dari pengujian ini didapati OAIGS, TFP, CAR, OEOI, NIM, dan LDR tidak berdistribusi normal, hanya terdapat data ROA yang berdistribusi normal pada angka JarqueBera 0.841985 lebih besar dari $5 \%$.
Untuk uji stasioneritas data, digunakan Augmented Dickey-Fuller Test Equation. Sebagaimana yang telah diuraikan sebelumnya, untuk menyederhanakan analisis maka data dalam bentuk nominal dikonversi ke dalam bentuk logaritma, sedangkan data dalam prosentase tetap digunakan. Hasil uji akar unit dengan Augmented Dickey-Fuller ditampilkan pada Gambar 2.

Berdasarkan Gambar 2 di atas, dengan melihat besarnya nilai kritis pada $\alpha=5 \%$ adalah $-3,450436$ yang lebih kecil dari nilai statistik t sebesar 9,805949, maka data sudah stasioner. Dengan demikian estimasi persamaan (2) dapat aplikasikan. 
Null Hypothesis: D(OSIGS) has a unit root

Exogenous: Constant, Linear Trend

Lag Length: 0 (Automatic - based on SIC, maxlag=0)

\begin{tabular}{lccc}
\hline \hline & t-Statistic & Prob.* \\
\hline \hline \multicolumn{2}{l}{ Augmented Dickey-Fuller test statistic } & -9.805949 & 0.0000 \\
\hline Test critical values: $\quad$ 1\% level & -4.042042 & \\
& 5\% level & -3.450436 & \\
$10 \%$ level & -3.150549 & \\
\hline \hline
\end{tabular}

*MacKinnon (1996) one-sided p-values.

Augmented Dickey-Fuller Test Equation

Dependent Variable: D(OSIGS,2)

Method: Least Squares

Date: 09/01/16 Time: 13:58

Sample (adjusted): 2007M03 2016M06

Included observations: 112 after adjustments

\begin{tabular}{lrlll}
\hline \hline \multicolumn{1}{c}{ Variable } & Coefficient & Std. Error & t-Statistic & Prob. \\
\hline \hline \multicolumn{1}{c}{ D(OSIGS(-1)) } & -0.937395 & 0.095595 & -9.805949 & 0.0000 \\
$\quad$ C & -0.530467 & 1.988219 & -0.266805 & 0.7901 \\
@TREND("2007M01") & 0.187524 & 0.035674 & 5.256600 & 0.0000 \\
\hline \hline R-squared & 0.468699 & Mean dependent var & 0.197248 \\
Adjusted R-squared & 0.458950 & S.D. dependent var & 14.01023 \\
S.E. of regression & 10.30538 & Akaike info criterion & 7.529630 \\
Sum squared resid & 11575.90 & Schwarz criterion & 7.602447 \\
Log likelihood & -418.6593 & Hannan-Quinn criter. & 7.559174 \\
F-statistic & 48.07832 & Durbin-Watson stat & 1.967991 \\
Prob(F-statistic) & 0.000000 & & \\
\hline \hline
\end{tabular}

Sumber: Output EViews Versi 9

\section{Gambar 2. Tampilan Hasil Uji Akar Unit}

Pengujian heteroskedastisitas dilakukan dengan metoda White Heteroskedasticity, hasilnya ditampilkan pada Gambar 3.

Uji White menggunakan residual kuadrat sebagai variabel dependen, dimana variabel independennya adalah variabel independen yang sudah ada, ditambahkan dengan kuadrat variabel independen, dan ditambahkan lagi dengan perkalian dua variabel independen. Dari Gambar dapat dilihat bahwa nilai Obs*R-squared pada hasil Gambar 3 adalah 67,68526 dan nilai probabilitasnya adalah sebesar 0,0000 lebih kecil dari $\alpha=5 \%$, maka disimpulkan data bersifat heteroskedastis.
Uji multikolonieritas dilakukan untuk mengetahui apakah antarvariabel bebas saling berhubungan secara linier atau tidak. Untuk pengujian digunakan uji Breusch-Godfrey atau disebut juga sebagai Uji Lagrange-Multiplier (Pengganda Lagrange) sebagaimana yang ditampilkan pada Gambar 4.

Dari Gambar 4, nilai probabilitas 0,2388 menyatakan bahwa $\chi^{2}>5 \%$ menunjukkan model sudah terbebas dari masalah auotokorelasi.

Dengan demikian estimasi persamaan dapat dituliskan sebagai berikut:

$$
\begin{aligned}
D \log (O S I G S)= & C(1)+C(2) * D \log (T F P)+C(3) * D(C A R)+C(4) * D(R O A)+C(5) * D(O E O I)+C(6) * \\
& D(N I M)+C(7) * D(L D R) \ldots(3)
\end{aligned}
$$

Dengan koefisien substitusi sebagai berikut:

$D \log (O S I G S)=0.0141866198921-0.235479471205 * D \log (T F P)-0.00229061006697 * D(C A R)+$ $0.00356612133916 * D(R O A)-6.98791080123 e 05 * D(O E O I)+6.15059866729$ 
Heteroskedasticity Test: White

\begin{tabular}{llll}
\hline \hline F-statistic & 4.654891 & Prob. F(27,86) & 0.0000 \\
Obs*R-squared & 67.68526 & Prob. Chi-Square(27) & 0.0000 \\
Scaled explained SS & 64.43921 & Prob. Chi-Square(27) & 0.0001 \\
\hline \hline
\end{tabular}

Test Equation:

Dependent Variable: RESID ${ }^{\wedge} 2$

Method: Least Squares

Date: 08/31/16 Time: 06:01

Sample: 2007M01 2016M06

Included observations: 114

\begin{tabular}{|c|c|c|c|c|}
\hline Variable & Coefficient & Std. Error & t-Statistic & Prob. \\
\hline $\mathrm{C}$ & -0.860333 & 0.480520 & -1.790420 & 0.0769 \\
\hline $\mathrm{LOG}(\mathrm{TFP})^{\wedge} 2$ & -0.030977 & 0.016111 & -1.922708 & 0.0578 \\
\hline LOG(TFP)*CAR & 0.002336 & 0.002645 & 0.883128 & 0.3796 \\
\hline LOG(TFP)*ROA & 0.016606 & 0.015288 & 1.086217 & 0.2804 \\
\hline LOG(TFP)*OEOI & 0.000281 & 0.001005 & 0.279827 & 0.7803 \\
\hline LOG(TFP)*NIM & 0.010415 & 0.003788 & 2.749649 & 0.0073 \\
\hline LOG(TFP)*LDR & -0.000445 & 0.001375 & -0.323931 & 0.7468 \\
\hline LOG(TFP) & 0.354684 & 0.121705 & 2.914295 & 0.0045 \\
\hline $\mathrm{CAR}^{\wedge} 2$ & 0.000587 & 0.000134 & 4.390440 & 0.0000 \\
\hline CAR*ROA & 0.000575 & 0.001033 & 0.556924 & 0.5790 \\
\hline CAR*OEOI & $-6.32 E-05$ & 4.12E-05 & -1.533093 & 0.1289 \\
\hline CAR*NIM & 0.000503 & 0.000201 & 2.504778 & 0.0141 \\
\hline CAR*LDR & -0.000176 & 0.000123 & -1.428969 & 0.1566 \\
\hline CAR & -0.023852 & 0.010011 & -2.382515 & 0.0194 \\
\hline $\mathrm{ROA}^{\wedge} 2$ & 0.005519 & 0.003074 & 1.795224 & 0.0761 \\
\hline ROA*OEOI & 0.000359 & 0.000338 & 1.061115 & 0.2916 \\
\hline ROA*NIM & -0.003569 & 0.001307 & -2.730817 & 0.0077 \\
\hline ROA*LDR & 0.000197 & 0.000768 & 0.256736 & 0.7980 \\
\hline ROA & -0.204996 & 0.067501 & -3.036920 & 0.0032 \\
\hline $\mathrm{OEOI}^{\wedge} 2$ & $-1.00 \mathrm{E}-05$ & 7.75E-06 & -1.293434 & 0.1993 \\
\hline OEOI*NIM & -0.000120 & $7.80 \mathrm{E}-05$ & -1.533416 & 0.1288 \\
\hline OEOI*LDR & $5.85 \mathrm{E}-06$ & 4.07E-05 & 0.143582 & 0.8862 \\
\hline OEOI & -0.000391 & 0.003627 & -0.107795 & 0.9144 \\
\hline $\mathrm{NIM}^{\wedge} 2$ & -0.000102 & 0.000147 & -0.690839 & 0.4915 \\
\hline NIM*LDR & -0.000352 & 0.000165 & -2.142436 & 0.0350 \\
\hline NIM & -0.040965 & 0.016705 & -2.452239 & 0.0162 \\
\hline $\mathrm{LDR}^{\wedge} 2$ & $3.08 \mathrm{E}-05$ & $3.28 \mathrm{E}-05$ & 0.936265 & 0.3518 \\
\hline LDR & 0.002611 & 0.004703 & 0.555150 & 0.5802 \\
\hline R-squared & 0.593730 & \multicolumn{2}{|c|}{ Mean dependent var } & 0.001435 \\
\hline Adjusted R-squared & 0.466181 & \multicolumn{2}{|c|}{ S.D. dependent var } & 0.002119 \\
\hline S.E. of regression & 0.001548 & \multicolumn{2}{|c|}{ Akaike info criterion } & -9.894020 \\
\hline Sum squared resid & 0.000206 & \multicolumn{2}{|c|}{ Schwarz criterion } & -9.221971 \\
\hline Log likelihood & 591.9591 & \multicolumn{2}{|c|}{ Hannan-Quinn criter. } & -9.621273 \\
\hline F-statistic & 4.654891 & \multirow{2}{*}{\multicolumn{2}{|c|}{ Durbin-Watson stat }} & 1.497009 \\
\hline Prob(F-statistic) & 0.000000 & & & \\
\hline
\end{tabular}

Gambar 3. Hasil Hitungan Regresi Uji White

Sumber: Diolah dengan EViews Versi 9 
Breusch-Godfrey Serial Correlation LM Test:

\begin{tabular}{llll}
\hline \hline F-statistic & 1.352502 & Prob. F(2,104) & 0.2631 \\
Obs*R-squared & 2.864584 & Prob. Chi-Square(2) & 0.2388 \\
\hline \hline
\end{tabular}

Test Equation:

Dependent Variable: RESID

Method: Least Squares

Date: 08/31/16 Time: 08:01

Sample: 2007M02 2016M06

Included observations: 113

Presample missing value lagged residuals set to zero.

\begin{tabular}{crcrr}
\hline \hline Variable & Coefficient & Std. Error & t-Statistic & Prob. \\
\hline \hline C & 0.000164 & 0.001757 & 0.093556 & 0.9256 \\
DLOG(TFP) & -0.014223 & 0.100470 & -0.141564 & 0.8877 \\
D(CAR) & -0.000244 & 0.002169 & -0.112276 & 0.9108 \\
D(ROA) & 0.000796 & 0.007227 & 0.110104 & 0.9125 \\
D(OEOI) & $1.63 E-05$ & 0.000256 & 0.063740 & 0.9493 \\
D(NIM) & 0.000304 & 0.001540 & 0.197646 & 0.8437 \\
D(LDR) & $-3.35 E-05$ & 0.001503 & -0.022288 & 0.9823 \\
RESID(-1) & 0.049777 & 0.098206 & 0.506857 & 0.6133 \\
RESID(-2) & -0.155943 & 0.098284 & -1.586663 & 0.1156 \\
\hline \hline & 0.025350 & Mean dependent var & 0.000000 \\
R-squared & -0.049623 & S.D. dependent var & 0.011187 \\
Adjusted R-squared & 0.011461 & Akaike info criterion & -6.023422 \\
S.E. of regression & 0.013661 & Schwarz criterion & -5.806196 \\
Sum squared resid & 349.3233 & Hannan-Quinn criter. & -5.935274 \\
Log likelihood & 0.338125 & Durbin-Watson stat & 1.943480 \\
F-statistic & 0.949235 & & \\
Prob(F-statistic) & & & \\
\hline \hline
\end{tabular}

Gambar 4. Tampilan Uji Breusch-Godfrey (Lagrange Multiplier) Terhadap Residual Sumber: Diolah dengan EViews Versi 9

Adapun grafik actual fitted dan residual disajikan pada Gambar 5 berikut ini.

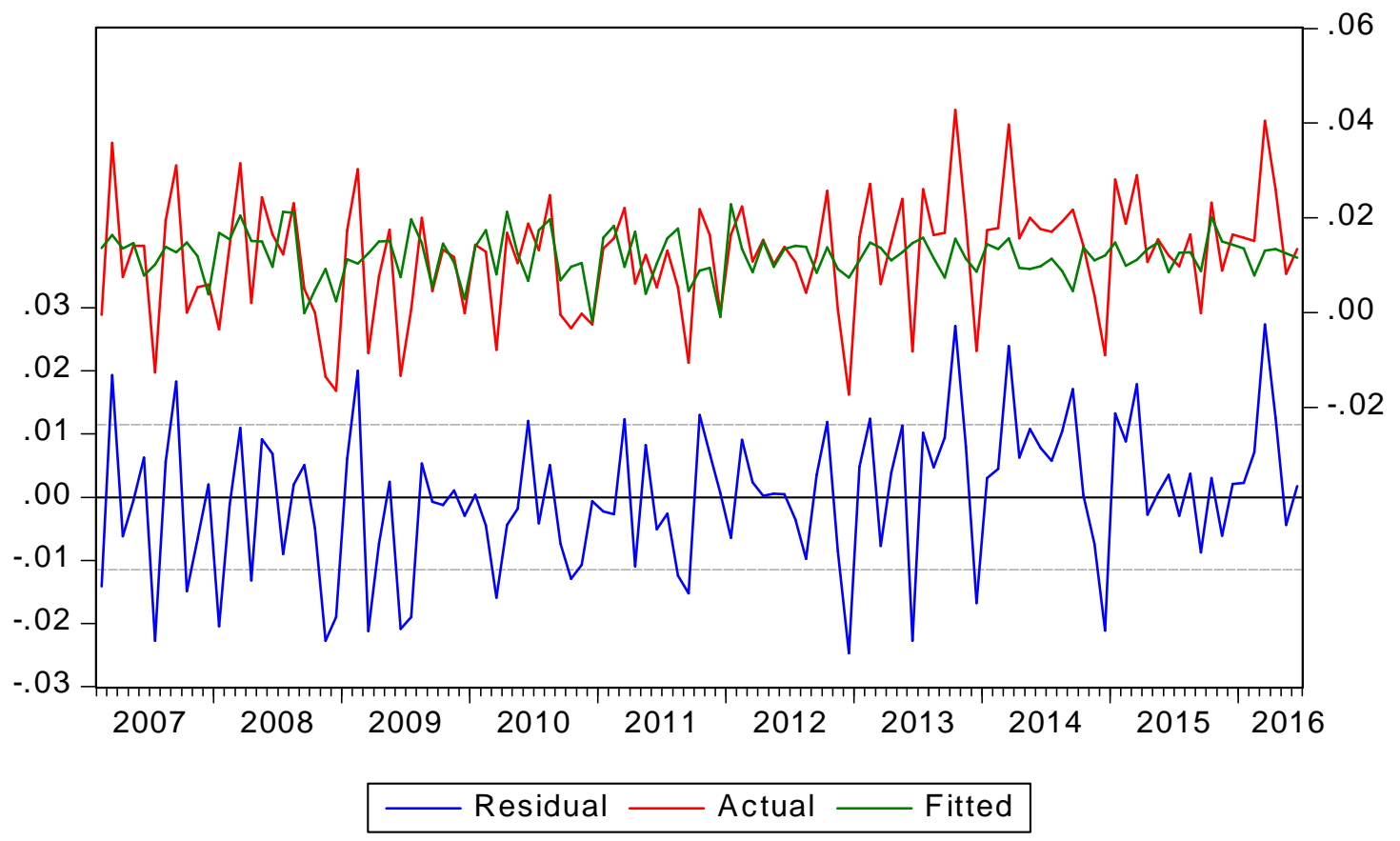


Model di atas, sekaligus melewati pengujian autokorelasi, heteroskedastisitas, dan multikolonieritas menunjukkan model telah memenuhi asumsi BLUE (Best Linear Unbiased Estimates). Model juga diuji dengan spesifikasi GARCH (Generalized AutoRegressive Conditional Heteroscedasticity) pada Gambar 6.
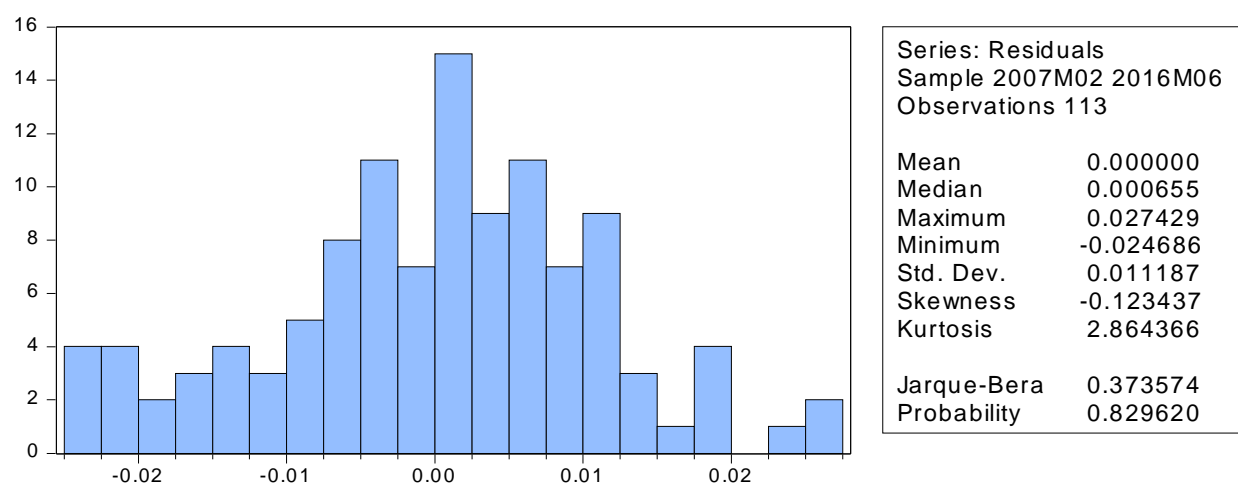

Gambar 6. Spesifikasi GARCH $(1,1)$ dengan Regresor Varian

Sumber: Diolah dengan EViews Versi 9

Korelogram pada Gambar 6 di atas menunjukkan bahwa residual berdistribusi normal. Hal ini ditunjukkan oleh kurva yang mengikuti bentuk lonceng, dan nilai statistik Jarque-Berra 0,373574 memiliki probabilitas yang jauh lebih besar dari $5 \%$. Dari hasil ini, model dapat dipakai untuk memprediksi OSIGS dan tampilan regresi tingkat satu sebagai model dapat dilihat pada Gambar 7 di bawah ini.

Dependent Variable: DLOG(OSIGS)

Method: Least Squares

Date: 08/31/16 Time: 07:54

Sample (adjusted): 2007M02 2016M06

Included observations: 113 after adjustments

\begin{tabular}{crlrr}
\hline \hline \multicolumn{1}{c}{ Variable } & Coefficient & Std. Error & t-Statistic & Prob. \\
\hline \hline C & 0.014187 & 0.001756 & 8.076935 & 0.0000 \\
DLOG(TFP) & -0.235479 & 0.100031 & -2.354073 & 0.0204 \\
D(CAR) & -0.002291 & 0.002171 & -1.054935 & 0.2939 \\
D(ROA) & 0.003566 & 0.007235 & 0.492929 & 0.6231 \\
D(OEOI) & $-6.99 E-05$ & 0.000255 & -0.273757 & 0.7848 \\
D(NIM) & $6.15 E-05$ & 0.001533 & 0.040118 & 0.9681 \\
D(LDR) & 0.001518 & 0.001506 & 1.007887 & 0.3158 \\
\hline \hline R-squared & 0.147942 & Mean dependent var & 0.012017 \\
Adjusted R-squared & 0.099713 & S.D. dependent var & 0.012119 \\
S.E. of regression & 0.011499 & Akaike info criterion & -6.033143 \\
Sum squared resid & 0.014016 & Schwarz criterion & -5.864190 \\
Log likelihood & 347.8726 & Hannan-Quinn criter. & -5.964583 \\
F-statistic & 3.067454 & Durbin-Watson stat & 1.902936 \\
Prob(F-statistic) & 0.008292 & & \\
\hline \hline
\end{tabular}

\section{Gambar 7. Tampilan Regresi Diferensiasi Tingkat 1}

Dari hasil yang pengujian dan penjelasan yang dilakukan sebelumnya, maka dari Gambar 7 dapat dideskripsikan bahwa pengujian Durbin-Watson Statistic 1,902936 tidak terdapat masalah auotokorelasi. Adapun DW terletak pada daerah penerimaan no-autocorrelation, yaitu $1,5 \leq \mathrm{DW}$ $\geq 2,5$. Hasil regressi dari persamaan (4) menampilkan bahwa dalam mempengaruhi variabel independen, variabel bebas cukup signifikan. Bila dilihat secara keseluruhan dari nilai Adjusted R- 
squared sebesar 0.099713, maka dapat dikatakan bahwa 6 (enam) variabel bebas mampu menjelaskan variasi variabel tidak bebas sebesar $9,9713 \%$ dan dapat dikatakan model relatif sudah baik, hal ini juga ditandai dengan tingginya nilai F-statistik 3.067454 yang signifikan pada pada $\alpha=1 \%$.

Hasil penelitian ini menunjukkan bahwa variabel yang berpengaruh terhadap pergerakan OSIGS adalah TFP, CAR dan LDR dengan signifikansi pada level $\alpha=1 \%$. Sedangkan ROA, OEOI dan NIM tidak berpengaruh pada pergerakan OSIGS. TFP dan CAR memiliki koefisien negatif yang berarti kenaikan oustanding IGS akan berpengaruh negatif terhadap TFP (DPK) dan juga CAR pada perbankan nasional, sedangkan LDR sebagai indikasi pergerakan ekonomi tetap dapat berlanjut kendati terjadi peningkatan outstanding IGS.

Kendati pengaruh penerbitan obligasi pemerintah Indonesia (IGS) tetap berpengaruh positif terhadap pertumbuhan LDR, ini mengindikasikan bahwa pertumbuhan penyaluran kredit sangat tergantung kepada CAR perbankan nasional. Artinya, sepanjang masih terdapat kelonggaran CAR di perbankan nasional, maka perbankan nasional masih terus dimungkinkan memberikan pembiayaan atau pemberian kredit yang dicerminkan oleh LDR yang positif dan bertumbuh.

Untuk TFT (DPK) yang terpengaruh negatif akibat penerbitan IGS, ini menyatakan bahwa secara signifikan terjadi pertempuran perebutan DPK antara Pemerintah dengan Perbankan Nasional. Kebijakan penerbitan IGS adalah sebagai sarana penciptaan utang kepada publik yang dapat diperjual belikan di pasar sekunder. Di pasar sekunder, dana investor yang diparkir di Perbankan Nasional dapat bersumber dari dana domestik dan dana Luar Negeri. Dengan terjadinya transaksi IGS, maka DPK yang ada di Perbankan Nasional akan beralih kepada Pemerintah melalui pooling fund yang dilakukan oleh Depkeu ke Rekeningnya di Bank Indonesia (BI) dan atau di rekening Perbankan Nasional dengan status dana diisolasi hanya untuk kepentingan pembangunan sehingga dapat mengerem LDR.

Untuk CAR, penerbitan IGS akan mengerem pertumbuhan CAR, karena yang memperbesar CAR adalah modal perbankan, bukan besarnya DPK yang dihimpun. Semakin besar modal Perbankan Nasional maka semakin tinggi CAR-nya, sehingga kelonggaran CAR yang ada melalui CAR yang dicapai dikurangi dengan CAR minimum, akan memungkinkan perbankan untuk tetap memberikan pembiayaan melalui pemberian kredit.

\section{SIMPULAN}

Temuan penelitian ini adalah: (1) TFP (DPK) dan CAR berpengaruh negatif terhadap kenaikan oustanding IGS, namun bilamana bank yang menerbitkan obligasi dalam rangka peningkatan modal maka akan berpengaruh pada ROA dan NPL (Septiana, 2010); (2) LDR tetap bertumbuh, kendati kenaikan oustanding IGS meningkat ini sejalan dengan penelitian Islam (2014) bahwa komponen utang dalam bentuk IGS memiliki pengaruh positif terhadap pertumbuhan ekonomi ditambah dengan kenaikan pertumbuhan uang giral; dan (3) ROA, OEOI dan NIM tidak mempengaruhi pertumbuhan oustanding IGS, namun bilamana bank yang menerbitkan obligasi subordinasi, maka modal berpengaruh secara signifikan terhadap ROA dan NPL (Sapulete \& Manurung, 2014).

Penelitian lanjutan dapat dilakukan dengan memasukkan IGS denominasi valuta asing yang tradable, agar akurasi penelitian semakin meningkat. Implikasi penelitian ini adalah bahwa penerbitan IGS oleh Pemerintah akan mempengaruhi DPK pada perbankan nasional, kendati pembatasan penerbitan IGS maksimal dibatasi sebesar 3\% dari defisit APBN terhadap PDB, namun secara volume, akumulasi nilainya meningkat terus. Implikasi lain adalah dikarenakan dibatasinya maksimum penerbitan oustanding IGS, maka ini akan menimbulkan problem bilamana defisit APBN meningkat melebihi 3\%. Sumber-sumber pendanaan lain harus dapat dikreasi, seperti bagaimana cara meningkatkan FDI (foreign direct investment) dan membentuk kolateral baru dalam meningkatkan permodalan perbankan nasional.

\section{REFERENSI}

Ariyanto, T., 2011. Faktor Penentu Net Interest Margin Perbankan Indonesia. Jurnal Keuangan dan Perbankan, 13(1), pp. 34-46.

Chee, S. W. \& Fah, C. F., 2013. Macro-economic determinants of UK treasury bonds spread. International Journal of Arts and Commerce, 2(1), pp. 163-172.

DJPBII-Kemenkeu, 2016. Laporan Keuangan Pemerintah Pusat (LKPPI), Jakarta: Kementrian Keuangan Republik Indonesia.

DJPPR Kemenkeu RI, 2016. Profil Utang Pemerintah Pusat: Pinjaman dan Surat 
Berharga Negara, Jakarta: Kementrian Keuangan Republik Indonesia.

Ekananda, M., 2014. Analisis Data Time Series: Untuk Penelitian Ekonomi, Manajemen dan Akuntansi. 1st ed. Jakarta: Mitra Wacana Media.

Gibson, H. D., Hall, S. G. \& Tavlas, G. S., 2011. The Greek Financial Crisis: Growing Imbalances and Soverign Spreads, Athens: Bank of Greece.

Gujarati, D. N., 2004. Basic Econometrics. 4th ed. New York: McGraw Hill.

Hendar, 2012. Fiscal Policy, Public Debt Management and Goverment Bond Markets in Indonesia, Basel: Bank For International Settlements.

Hubbard, R. G., 2001. Money, the Financial System, and the Economy. 4th ed. New Jersey: Addison Wesley.

Islam, M., 2014. Pengaruh Utang Pemerintah Terhadap Pertumbuhan Ekonomi Indonesia, Bogor: Institut Pertanian Bogor.

Kempf, A. \& Uhrig-Homburg, M., 2000. Kempf, A. and Uhrig-Homburg, M., 2000. Liquidity and its impact on bond prices. Schmalenbach Business Review, 52(1), pp. 26-44.

Mehrotra, A., Miyajima, K. \& Villar, A., 2012. Developments of Domestic Government Bond Markets in EMEs and Their Implications, Basel: Bank For International Settlements.
Min, H. G., 1998. Determinants of Emerging Market Bond Spread - Do Economic Fundamental Matter, Washington DC: World Bank.

Mishkin, F., 2016. The Economics of Money, Banking and Financial Markets. 7th ed. Boston: Pearson.

Samuelson, P. A. \& Nordhaus, W. D., 2010. Economics. 19th ed. New York: McGraw-Hil.

Sapulete, A. M. \& Manurung, A. H., 2014. Pengaruh Penerbitan Obligasi Subordinasi dan Rasio Keuangan terhadap Profitabilitas Bank. Journal of Capital Market and Banking, 2(1), pp. 80-101.

Septiana, T., 2010. Dampak Penerbitan Obligasi Subordinasi Terhadap Struktur Modal PT. Bank DKI, Jakarta: Universitas Indonesia.

Sihombing, P., Siregar, H., Manurung, A. H. \& Santosa, P. W., 2013. Determinan Yield Curve Surat Utang Negara. Jurnal Keuangan dan Perbankan, 15(1), pp. 68-89.

Simatupang, B. M., 2007. Bank Recapitalization and Bank Performance in Real Sector Lending: Analysis of Indonesia's Economic Recovery from the Crises of 1997-1998. Maastricht: Maastricht School of Management. Simatupang, B. M., 2012. Deja Vu Obligasi Rekapitalisasi, Jakarta: Harian Bisnis Indonesia.

Vogelvang, B., 2005. Econometrics Theory and Application with EViews. Harlow: Pearson. 